Article

\title{
Circular Economy for Food Policy: The Case of the RePoPP Project in The City of Turin (Italy)
}

\author{
Franco Fassio ${ }^{1, *}$ (1) and Bianca Minotti ${ }^{2, *}$ \\ 1 University of Gastronomic Sciences, 12042 Pollenzo, Italy \\ 2 Department of Economics Policy and Administration, Czech University of Life Science Prague, Praha \\ 6-Suchdol, 165000 Prague, Czech Republic \\ * Correspondence: f.fassio@unisg.it (F.F.); minotti@pef.czu.cz (B.M.); \\ Tel.: +39-0172-458544 (F.F.); +39-3488-847433 (B.M.)
}

Received: 18 September 2019; Accepted: 29 October 2019; Published: 1 November 2019

\begin{abstract}
Circular economy for food (CE) and food policies (FP) are two emerging but already prominent research areas, particularly when talking about the cities of the future. This paper analyzes the dynamics between these two fields of research, starting from review articles and the analysis of a case study, underlying the fundaments that FP and CE share. In particular, this paper focuses on using circular economy (CE) indicators and strategies to shape urban food policies (FP) to create a new business and political model towards sustainability. It introduces four converging perspectives, emerging from the literature, and analyzes how they have been integrated in the case study RePoPP (Re-design Project of Organic waste in Porta Palazzo market), a circular project born from the FP of the City of Turin (Italy). RePoPP is indeed a multi-actor project of urban circular food policies against food waste, which demonstrates how a circular approach can be the turning point in the creation of new food policies. This article wants to define for the first time a new research framework called "circular economy for food policy", along with its characteristics: the application of a systemic approach and $\mathrm{CE}$ to problems and solutions, the need for a transdisciplinary and integrated project design for the 9R (responsibility, react, reduce, reuse, re-design, repair, recover, recycle, and rot), the use of food as a pivot of cross-sectoral change, and a new form of collaborative and integrated governance.
\end{abstract}

Keywords: circular economy; food policy; sustainable strategies; systemic design; gastronomic sciences; food waste; responsibility; reduce; recover; human health

\section{Introduction}

Growing urbanization poses new challenges and problems to the world, many of which are related to food production and consumption. The percentage of people living in city environments has recently reached more than half of the global population and is set to grow further [1], reaching $80 \%$ by 2050 [2]. As population increases, the demand for resources in urban areas grows, environmental problems increase, socio-economic differences among citizens expand [3], and new energy needs arise [4]. A new food insecurity has crossed the threshold of cities all around the world, no longer relegated to under-nutrition but characterized by a double burden of malnutrition, namely the coexistence of a lack and excess of nutrition $[5,6]$. In fact, the increased risk of mortality associated with the poor nutritional value of food has exceeded that of diseases relating to lack of calorific intake. While one third of the world's population has food security problems (about 868 million undernourished people), 1.5 billion people are obese or overweight. The approximately 29 million deaths worldwide due to overeating are rapidly reaching the 36 million caused by food shortages [7].

Presently, and most likely in the future, urban environments will be the central point for systemic change, rippling through from local to a global change. The 11th Sustainable Development Goal [8] 
reminds us that there is a priority to "make cities and human settlements inclusive, safe, durable, and sustainable", and important realities are already following this path [3]. Some examples include cities that are proposing a return to a slower and more traditional life, or a new focus that pushes a proactive role of humans in the system [9], or that aim to create smart cities, sparking many controversies and debates [10-12]. In essence, all the urban projects aiming at creating "the cities of the future" apply different tools but share similar goals [10]. In particular, they all share the desire to move towards a socio-economic paradigm shift. Fundamentally, integrated polices are key, particularly food policies, which strengthen existing economic, social, and environmental ties to improve citizens' wellbeing [1]. This paradigm essentially works to include, as opposed to exclude, citizens and applies a systemic approach to design and analysis of policy.

What will be the role of food in the cities of the future? The intersectoral nature of food plays a primary role in circular and sustainable urban development: from the supply chain to the many cultural links, food has a mass impact on human lives, especially since the globalization of food influences ecosystems and economies, long before it reaches our plate. With this in mind, food can act as the lever for sustainable change in this urban context [3,13], a lens to uncover the interconnected problems and find systemic solutions [14]. Food can help to move away from a classic "anthropocentric" vision that sees man at the center of the urban system, as problem and solution [9], to an "ecocentric" one, which sees humans as an essential part of an ecosystem in which systems exist in relation to other systems [15]. With this vision, actors within the city play an important role, paramount to this is their interaction with each other, the formation of relationships, and the exchange of matter, energy, and knowledge [16]. Therefore, in this heterogeneous worldview [9], what surrounds human in an urban system has the same importance as human themselves.

Humanity needs urban policies that can respond to these new challenges [12], involving more actors, sectors, and political levels [3]. In particular, society needs to stop implementing emergency food policies, namely solutions that do not tackle upstream issues or make effective change [3]. However, which tools should be used to shape future scenarios, adopting an integrated, holistic, system perspective? This paper proposes the use of the principles of circular economy (CE) and a systemic approach as tools to develop urban food policies. Indeed, the CE strategies can help us evolve our intuitions on the entire food system, refine our ability to understand its parts, see the fundamental interconnections needed to challenge the future, to be creative and courageous about the redesign of the system [17].

The Ellen MacArthur Foundation (EMF) opened the path for a new discipline to emerge with the publication Cities and Circular Economy for Food, which addresses the need to apply CE to cities' challenges around the food system [2]. Also, previous studies, such as Fassio and Tecco 2018, associated the strategies of $\mathrm{CE}$ with the food system by supporting their fundamental and primordial relations [16]. Starting from these two main previous studies, the aim of the paper is to answer an important, yet complex, question: can the use of CE strategies and worldview help bring a socio-economic paradigm change in food policies design? The case of RePoPP (Re-design Project of Organic waste in Porta Palazzo market) has been selected to illustrate the strength of the circular and systemic approach into the context of anti-food waste urban policies, as the national leader example of a new design of this type of projects.

\section{Materials and Methods}

This article analyzes the emerging scenario of the circular economy for food, placing it in relation with the food policies world, with the aim of understanding how the two concepts are interconnected. A series of reviews on $\mathrm{CE}$ and the most relevant literature on food policies have been selected according to (1) topic of interest and (2) comparison to present economic growth and more alternative sustainable patterns. The literature review for $\mathrm{CE}$ was performed using the web of science databases, searching for words like "circular economy", "circular economy for food", "food waste"; while regarding food policy, the data was gathered from a specific body of knowledge that advocates for more integrated food 
policies. However, the interdisciplinarity of the topic limited the possibility to produce a systematic literature review. In fact, as Table 1 shows, recent review papers, published from 2012 to 2019 , were selected, which provided a broad overview of the concept of CE (410 articles, 1270 interviews, over 100 case studies, 45 strategies), along with other important papers on CE and sustainability. Regarding the other two areas of study, a lack of review articles obliged a less comprehensive document selection, and thus only core and fundamental documents were chosen, following previous knowledge (Table 1).

Table 1. Relevant literature on Circular economy, Circular economy for food, and Food policy.

\begin{tabular}{clll}
\hline \multicolumn{2}{c}{ Circular Economy } & \multicolumn{1}{c}{$\begin{array}{c}\text { Circular Economy for } \\
\text { Food }\end{array}$} & \multicolumn{1}{c}{ Food Policy } \\
& & & OECD, 1981 \\
& 155 articles on CE & & Nestle, 2002 \\
& 148 articles for148 articles & & Maxwell and Slater, 2003 \\
Ghisellini et al., 2016 & for 114 definitions of CE & & Lang, Barling and \\
Kirchherr et al., 2017 & 67 articles on CE and & Fassio and Tecco, 2018 & Caraher, 2009 \\
Geissdoefer et al., 2017 & sustainability & Ellen Mac Arthur & Pinsturp-Andersen and \\
Borrello et al., 2017 & 1270 interviewees & Foundation, 2019 & Watson, 2011 \\
Kalmykova et al., 2018 & 45 CE strategies and over & & Lang and Heasman, 2015 \\
Korhonen et al., 2018 & 100 case studies & & Hawkes, 2017a \\
& 40 articles on CE & & Hawkes, 2017b \\
& & & Lang, 2017 \\
\hline
\end{tabular}

The main conclusion of this first part was the identification of four converging perspectives, common to the circular economy for food and food policies. These perspectives have been selected as bridging points between $\mathrm{CE}$ and FP, specifically when $\mathrm{CE}$ is directly associated with food, as in the case of the new body of literature CEFF. Namely, they become common perspective only under the lens of a food system. Therefore, since CEFF and FP are new bodies of knowledge, only qualitative data have been harvested and the review on CE has been used to support the very new literature around CEFF.

Then, a detailed analysis of a case history of CE applied to urban food policies in the city of Turin (RePoPP), the outcome of the local policies and the Atlas of Food's research (Appendix A), was analyzed. This case study helped to highlight the effectiveness of strategic projects related to the use of a systemic approach. The application of CE to problems and solutions in the food system, also adopting a transdisciplinary and integrated project design for the $9 \mathrm{R}$ (responsibility, react, reduce, reuse, re-design, repair, recover, recycle, and rot) was explained. This case study was chosen because it is an example of how the four converging perspectives were integrated with each other within an applied research project. Furthermore, it is a multi-award-winning project at national and international level (Milan Pact Award, Cresco Award, Oscars of Health) which is independently spreading in the City of Turin and other Italian cities. The data collected on the RePoPP project are the result of the work of all the actors involved in the research and scientifically coordinated by the University of Gastronomic Sciences (UNISG). In particular, Amiat Grouppo Iren, urban waste company of the city of Turin, gathered the data on recycling, while Eco delle Città, local NGO, assessed foodstuff weight. Crossing the design strategies adopted for the realization of RePoPP with the four converging perspectives, four fundamental application strategies emerge, which could become the ground for dialogue about the circular economy for food and the food policies: a first definition of circular economy for food policy.

It is important to underline that the methodological approach used for this article was exploratory. Exploration in social sciences is intended as scientific process which aims to "generate new ideas and weave them together to form grounded theory, or theory that emerges directly from data" [18]. In fact, exploratory research works with posteriori hypotheses by analyzing data and the relationships between them. This methodology is normally used to discover new developments in the research world and can be particularly useful when working with a set of field studies that are linked together, 
producing what is called a "concatenated exploration" [19]. As in the case of CE and FP, this type of exploratory research works with data from different fields that are linked together in a sort of chain.

\section{Results}

\subsection{Food Policies and Circular Economy for Food: Two Interconnected Concepts}

Tim Lang, food policy professor at City University of London and one of the founding fathers of the concept of "food policies", describes them in a deliberately reductive way as those policies that deal with "who eat what, when, and how, whether people (and animals) eat and with what consequences" [20] (p. 21). This definition, generic but accurate and punctual, perfectly delineates the holistic nature of these policies that shape and regulate the food system as a whole [21]. However, these policies are too often managed in a sectorial and discontinuous manner, but instead should require, by their nature, an integrated management, not only horizontally between policy sectors but also and above all through different levels of governance [22]. Within this assumption, this paper inserted the CE model as an umbrella concept that aggregates different approaches and levels, with the aim to give circularity, efficiency, and eco-efficiency to the business as usual (BAU) model. CE is indeed an alternative model based on the assumption that a shift from a linear economy "take, make, and dispose" to a circular and regenerative one which dialogues with nature is needed because the current economy creates an apparent fragile abundance [16].

In this new scenario, several urban food policy strategies are already trying to connect, within a circle, different sectors, such as health and nutrition, education and the environment, work, justice, and social cohesion [23]. However, the process necessary to treat food as an urban infrastructure interconnected with the surrounding environment [13] to adopt this circular perspective is still considerable. The current food system's geopolitical challenge, at a global as well as local level, still remains the transformation of our productive model towards a correct management of natural [24] and cultural capitals [25], by respecting the planetary limits [26] while offering at the same time a fair space for civil society [27]. To reach this transformation, we need to avoid compromising relations with the best raw material supplier mankind ever knew [24] and start proposing urban policies that understand that "circularity" already belongs to humans and the context in which they live. In fact, humans are an open system [28] that develops circular dynamics, like the one that starts inside our body when we eat something. Food is the medium through which the circular process of metabolism in the human body begins and its consequential transformation into energy for life [29]. This same intuition led the German philosopher Ludwig Feuerbach to the conclusion that "we are what we eat".

Circularity is not an invention of our time. It has always been a life companion of sustainability and now it needs to become a tool for food policies. Therefore, mentioning the CE does not mean only reducing waste by finding a new destination of use for a by-product or waste, namely trash to treasure strategies. Starting from food to develop a paradigm shift in a circular framework means bringing attention back to communities, quality of relationships, and substance of behavior [30]. It means not only dealing with what keeps us alive, but exploring complex territories that relate to sociality, to personal and public identity, to the spirituality of each human being. It means recognizing the central role of food for our survival in the urban context, the sustainability of our planet, the value of food for the health, well-being, and prosperity of all humans. Food is an interconnected urban infrastructure [13] that has to be designed and managed in a circular way.

\subsection{Four Converging Perspectives}

Currently, the worlds of food policy and circular economy for food share principles and mutually influence each other, generating shared solutions in a way that is not yet evident. The vast literature on CE enlighten some of the most important fundaments on which this concept is based. Review articles such as Ghisellini et al. (2016), Kirchherr et al. (2017), Geissdoefer et al. (2017), Borrello et al. (2017), Kalmykova et al. (2018), and Korhonen et al. (2018) help identify the core principles of the CE 
by analyzing and synthetizing the long history of this world of knowledge. In particular, they show how $C E$ is first of all grown from a specific vision of the world and economy we live in, which sees the current business model as completely unsustainable. Second, they agree upon the idea that CE will help in redefining this system by giving sustainable development a new tool and theoretical background [31]. EMF defines it as an "alternative growth discourse, not an alternative to growth discourse," [31] (p. 12) shining light on the need for a paradigm change.

The systemic approach seems to be essential in the definition of $\mathrm{CE}$, as much as the strong focus on waste management and the 4 Rs (reduce, reuse, recycle, recovery) or 3Rs (reduce, reuse, recycle) principle [32]. Also, interdisciplinarity and transdisciplinarity are seen as indispensable for this discipline, along with a united series of bottom-up and top-down approaches [33] to create a new form of cross sectoral and multi actor system [34]. The definition of CE given by Korhonen et al., indeed, is explicit about all these features: " $\mathrm{CE}$ is a sustainable development initiative with the objective of reducing the societal production-consumption systems' linear material and energy throughput flows by applying materials cycles, renewable and cascade-type energy flows to the linear system. CE promotes high value material cycles alongside more traditional recycling and develops systems approaches to the cooperation of producers, consumers and other societal actors in sustainable development work" [34] (p. 547).

The same scenario is set by modern food policy literature, which is still too young to have a review article but is deeply analyzed by some authors, such as Lang et al. (2009), Nestle (2002), Lang and Heasman (2015), Hawkes (2017). In fact, the literature selected for this article around FP are a new body of literature that aims to reconfigure food policies all around the world. As previously explained, food policy put food at the core of a new series of change that, from an unsustainable food and policy system $[19,35,36]$, will provoke a domino effect of sustainable solutions exemplified by a new socio-economic paradigm if intended as eco-integrated [36]. Indeed, the food wars theory [36] perfectly explains how the linear economic and political system created an unsustainable system that needs to change into a more radical way of thinking about food and its relationship with society and nature. For instance, the International Panel of Experts on Sustainable Food Systems, promoter of this new way of conceiving food policies since 2015, advocates the need for a more integrated set of European food policies that would transform the Common Agriculture Policy into Common Food Policy [14] —a holistic and sustainable approach towards food, that sees the food system as a whole where sustainable diets should be achieved through "a better alignment of consumption with ecosystems" [37] and societies.

Considering the interesting debate between "old" and "new" food policies [38], along with the emergence of an integrated approach, firstly claimed by OECD in 1981 and then reclaimed by Lang et al. (2009), Lang and Heasman (2015), and Hawkes (2017), they share several preconditions and solutions with CE when applied to food. Indeed, the modern literature on food policies demands the reconfiguration of this type of policy as much as $\mathrm{CE}$ for a new economic model. Combining the data from CE and FP literature, it becomes clear how four converging perspectives, usually reported in the introduction or in the final considerations, can be identified as clear areas of research and development, both in the field of CE applied to food and of food policies. Hence, in this section of the article the authors will try to provide a summary of scientific data and considerations deriving from further publications, which highlight the importance of these four perspectives of analysis.

Indeed, a new body of literature is now growing which relates food and CE, considering food as a pivotal element of change but using CE principles and indicators. This concept of a circular economy for food, which was mainly proposed by Fassio and Tecco (2018) and EMF (2019), has been briefly discussed in Section 3.1 and will be the core of this article. The following perspectives are nothing but assumptions and solutions that both CE applied to food and food policies present in their body of knowledge.

1. The current food system is harmful and unsustainable: From an environmental and cultural perspective, we are converging towards the promotion of food commodities, feeding the economy 
itself rather than responding to the real needs of humanity [39]. A "crisis of reason" is leading our society [40], which is revealed in the total irrationality of food loss and food waste [41,42] and billions of liters of wasted water and hectares of wasted land [43], or the extraction of primary materials (such as metals, biomass, fossil fuels, and minerals) which tripled from 1970 to 2010. It is estimated that in 2050, in order to maintain stability, the current production and consumption rates, about 180 billion tons of natural resources-20 tons per year per capita-will be necessary to feed this system. However, among these tons, around 29 billion will be missing [44]. In 2050, when the world's population will exceed 10 billion people, not only will primary resources be a problem, but energy demands will increase by $30 \%$ also due to the fact that we will have to support a $70 \%$ increase in agricultural production $[45,46]$. This is a situation that the world will have to face shortly, as much as reducing emissions harmful to the ecosystem, which should be reduced by $50 \%$ before 2030 [47] if we want to avoid unpredictable consequences. Many other indicators, such as animal welfare, water acidification, soil, and human health, show how inside the food system, everything is connected in a relationship of mutual evolution or involution, especially in the urban context. Huge amounts of resources enter our cities daily, to be transformed and consumed, creating mountains of food waste that are almost never re-introduced in the production system [2]. Cities consume $75 \%$ of global natural resources and $80 \%$ of world energy, and it is estimated that by $2050,80 \%$ of food will be consumed in the same circumstances. The path to improve urban systems is long and complicated, mainly because the current economic model is only $9 \%$ circular, and this percentage, already dramatically low, is decreasing [48].

2. A paradigm shift is needed: Cities are systems within systems, in which overlapping networks interact on different scales. Multiple actors and connections among them characterize the urban food system, determining a living organism in which there are flows of matter, energy, and knowledge that actors exchange, define the urban metabolism. Cities are resource-intensive ecosystems; therefore, rethinking them in terms of flows, and not only spaces [4], becomes essential to understand how to design them to make an alternative approach grow. Urban areas are clearly dynamic systems composed of stock, flow, and feedback loops [49], in which the equilibrium between parts is more important than the sum of the single elements [17], in which any actor of the system cannot exist alone but each of them exists only because of the place they occupy within the system [50]. The new economic paradigm of the CE places citizen at the center of the system and proposes a completely different way of living and conceiving the urban community. Through a responsible involvement of public administration, which is entrusted with the task of educating people and creating interest, the circular model aims primarily to ensure that urban metabolism does not produce waste, but economic and social values in balance with natural ecosystems. Here, food policies acquire meaning and value as those policies that expand the potential of urban systems: through the participation of all urban food actors and the interconnections that characterize them, with the circularity lens, food policies can develop a cooperative model tending towards zero waste. Many organizations are trying to shape this transition to sustainability through the development of systemic policies [14] guided by the word "integration" among all the actors of the same urban system. A new paradigm is followed, which sees total cooperation of practices and intents between agriculture and environment, public health, and transport, trade, and education [2,3,14,22,47]: a widespread "great food transformation", multisectoral and multilevel, global and local, with the ultimate aim of guaranteeing healthy, fair, and sustainable food to all citizens of the world, impacting as little as possible on land resources by closing the system circle economic [47].

3. Food as the measure of change: Food can be the pivot for a domino effect of changes if intended, as the natural outcome of an alliance between parts of a system [16]. The metrics of the model called The Wedding Cake, developed by Rockström and Sukhdev of the Stockholm Resilience Center [51], show that food is the only actor in relation to all 17 Sustainable Development Goals, objectives that in September 2015, 193 member countries of the UN pledged to reach by 2030 [8]. 
This is a model in which the basis of the "cake" is the dimension of the biosphere, which contains and supports the social and economic structure. This is because the intrinsic nature of food is to influence health, the environment, society, and all sectors related to them. The food chain is a bundle, an intricate network of actors, powers, and sectors, connected to each other by those products that we find on the plate every day. This set of interconnected networks inevitably causes problems that cannot be solved in any way other than a systematic approach [14]. The cities of the future will therefore have to put food at the core of their political agenda and "use food as a key to stimulate innovation in other sectors" [13] (p. 45). Interpreting food as an essential and fundamental right of the citizen will be the only way to give back the right value to food, not only as a product, but as the keystone of a more complex urban architecture.

4. A new governance is needed: The term governance is always complicated to define, it is a concept closely linked to the processes of policy formulation and to those who hold power [52]. Usually, the term refers to a form of indirect and flexible government, which involves both private and public actors, looking for collaborative results [20]. It is therefore clear that to change mentality and the current paradigm, a new governance system is needed. The first objective of the circular mindset is to avoid the constant breaking down of complexity that surrounds us in linear logics of thought [53], in a set of independent sub-problems: a problem solving approach that loses the transdisciplinarity [54] of the scientific and intellectual approach that aims at the full understanding of the complexity of the present world. This linear way of thinking made environmental and social degradation an obvious error of the system [30]. Therefore, the first step consists of acquiring a community awareness that unites the human race in recognizing the entire Earth as "homeland" [55] and in this sense, in implementing policies of collaboration for the common well-being. According to Haysom, "urban food governance innovation" is the last essential piece of a series of interconnected transitions that the world has lived and is living in its relationship with food [56]. In the CE and in food policies, governance means a political-social management system that includes multiple levels of power: local, national, and international governments, citizens and NGOs, academia, and private businesses [14]. Everyone takes part, everyone contributes, everyone benefits: a "governance for transition" [14] that facilitates and guarantees the integration and circularity necessary for the paradigm shift. This new governance system includes not only public bodies but also the whole supply chain, "where the hierarchy is no longer a value but exclusively a relationship and a function, where each node of the network has equal importance precisely because it is part of a whole" [16] (p. 59). Only a participatory, collaborative, inclusive, diversified governance of this kind would facilitate the development of an economy that functions in the long term as regenerative [2].

\subsection{Theory Applied: The Case of RePoPP Project in the City of Turin}

Some cities, pioneers of innovative urban food policies or CE strategies, have long been working on a "new food equation", intending cities as leaders of a strategic vision of the food system, that take advantage of the interactions of food with other sectors and where political public institutions play a proactive role in solving problems [57]. The report of the Ellen Macarthur Foundation of 2019, Cities and Circular Economy for Food, describes how cities can have an impact on the food system by applying the principles of the $\mathrm{CE}$, in three macro-categories: food production through regenerative methods within urban and peri-urban areas; distribution and design of healthy products contained in sustainable packaging; reuse or recycling of food outputs, waste, and by-products that must become inputs for new systems [2]. For each of these categories, there are currently cities that are developing the best practices.

Dakar and Daegu, for instance, are proposing solutions to food poverty, climate change, food waste, and social exclusion, which involve urban and peri-urban agriculture, in particular, micro-gardening and the cultivation of rice fields [58,59]. The municipality of Porto Alegre has instead given economic and infrastructural support to producers of organic seed oil and derivatives, guaranteeing empowerment of 
local producers, creating new jobs, and preserving the biodiversity of the area [60]. Ljubljana, Moscow, and Vienna, on the other hand, present policies related to food distribution and access: a public marketing strategy for rural products in the area [61]; the creation of an infrastructure that guarantees access to fresh and local food [62]; a regulation for sustainable procurement in public facilities [63], respectively. Finally, Riga and Milan have projects both aiming at better waste management and the re-use/redistribution of food waste and surpluses: in Riga, directly in the landfill [64] and in Milan, at neighborhood level [65].

This brief overview of best practices exemplifies the vast panorama of urban food policies that apply the principles of the CE for food to develop integrated, contextualized, and effective policies. Precisely from the analysis of these practices, Turin took the inspiration to develop RePoPP—Progetto valorizzazione organico Porta Palazzo (project for the organic development of Porta Palazzo). This initiative-promoted by the Municipality of Turin, Novamont, the NGO Eco dalle Città, Amiat-Iren Group, with the scientific coordination of the University of Gastronomic Sciences (Project Manager for UNISG: professor Franco Fassio)—is an example of research applied for the design of urban circular policies against food waste (Figure 1).

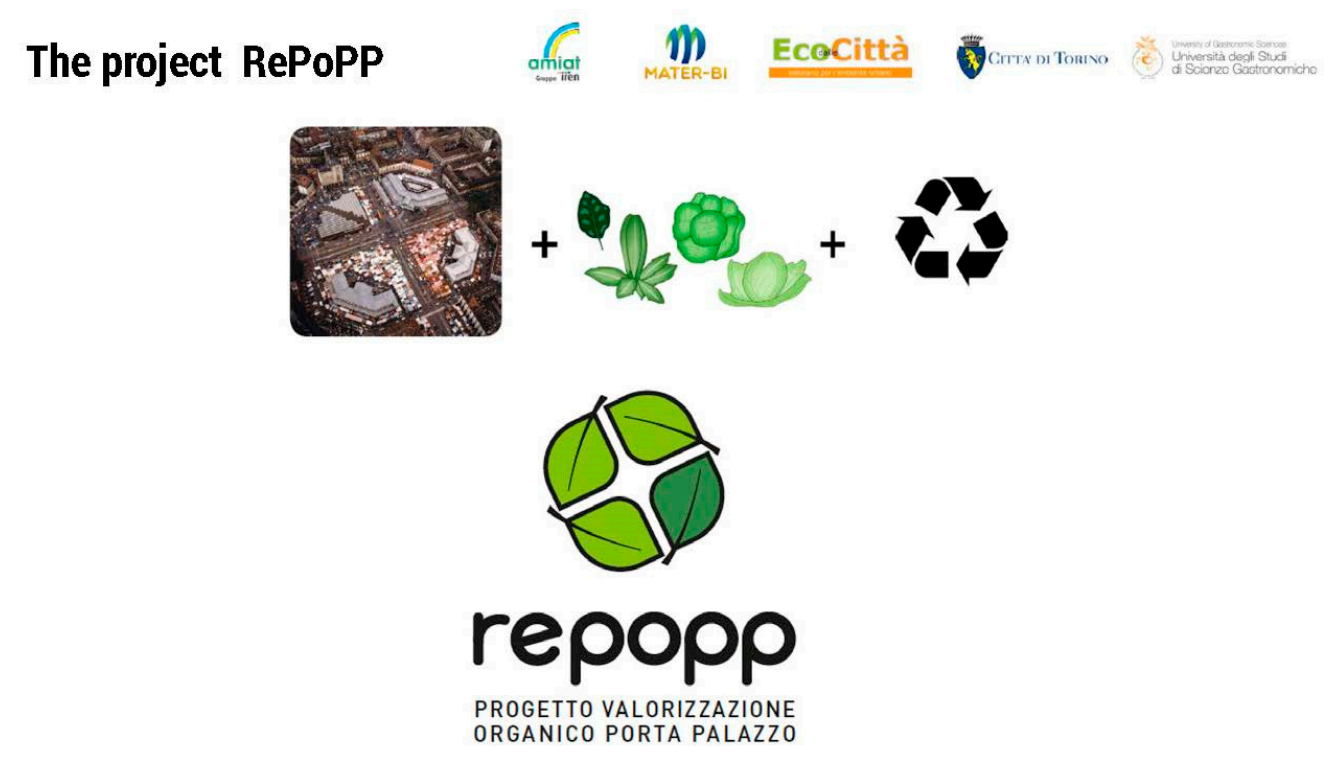

Figure 1. The RePoPP Project (Source: University of Gastronomic Sciences, 2018).

This project was born from the analysis of the food system of the Metropolitan City of Turin performed by the Atlas of Food, a transdisciplinary research and open platform which, through a systemic approach to urban research, helps to understand the complexity of food and its connections with urban and peri-urban areas (Appendix A). The Atlas, developed from the collaboration between the University of Turin, Turin Polytechnic, and the University of Gastronomic Sciences in collaboration with Camera del Commercio di Torino, was born with the desire to provide a research database to support public policies as much as private businesses initiatives [66]. Therefore, RePoPP started in 2016 during the European Week for Waste Reduction (EWWW) and was developed thanks to the NGO Eco dalle Città, which involves the Waste Sentinels and the Ecomori (volunteers requesting asylum), in the recovery of food surpluses at the market stalls of the Porta Palazzo market (recover). The redistribution of food recovered occurs through the use of fruit and vegetable boxes filled with a mix of food aimed at satisfying, both from the quantitative and qualitative/nutritional point of view, the needs of a standard family for two days (humane health). From November 2016, the surplus food is recovered daily, and $150,649 \mathrm{~kg}$ of food has been collected to date, thanks to the work of 43 volunteer asylum seekers and two awaiting residence permits (react), coming from Pakistan, Ghana, Ivory Coast, Mali, Gambia, Nigeria, and the Republic of Guinea. Furthermore, in 2019, two work contracts and five internships were activated with the prospect of further involving other non-volunteer workers. 
Besides storing the surpluses in a market counter and a refrigerated cell, given free of charge by the Municipality of Turin for the implementation of the project (reuse), the Ecomori also play the role of sensitizing the staff of the market to a correct recycling (responsibility). Waste is, in fact, another area where RePoPP is achieving excellent results. The Porta Palazzo market generated about 4000 tons of waste per year in 2016, for an annual cost for cleaning spaces of 1,800,000 euros. The general waste represented $47.5 \%$ of the total waste, $14.7 \%$ of which was organic waste. The project therefore wanted to impact the organic part of the waste, delivering to the vendors 165 perches and 206 packs of biodegradable and compostable bags made of Mater-Bi, for the collection of organic waste produced during the sale (recycle and rot). From the beginning of the project to March 2019, around 15,000 bags were distributed every month and the quality of recycling improved, showing a significant drop in the organic fraction in the general waste and demonstrating the success of the project.

The Mater-Bi bags have been widely accepted by traders, who are currently refurnished weekly with 25 packs. The perch, on the other hand, has had some resistance: if at the beginning of the project $30 \%$ of the traders had adopted it, a year later only $14.5 \%$ continued to use it, essentially due to the lack of space among the stalls (re-design). The quality of the waste has, however, improved: the first data found a decrease in the amount of organic materials inside the general waste that was incinerated, and a decrease in the quantity of recycling waste among recovery waste. In 2016, the market had produced 4267 tons of waste, while in 2017 it produced $8.9 \%$ less (a reduction of around 380 tons). The greatest achievement in the area of waste management was the reduction in general waste: from 2289 tons in 2016 to 1579 tons in 2017, a drop of 31\% (reduce). Given the nature of the project, the production of organic waste grew significantly, by 95\%, going from 416 tons in 2016 to 811 tons in 2017, while regarding what is called "cassettame", that is, the other material sent for recycling (repair), the latter recorded an increase of $4.1 \%$ (equal to just over 64 tons). This year, in Porta Palazzo, the collection continued, gaining momentum, and collected a total of 30,234 kg between January 1st and June 30th. Starting from March 2019, the total number of Mater-Bi bags distributed among the vendors has decreased in order to adapt the quantity of bags to the specific needs of each merchant and avoid waste or shortages. Comparing the data from the first half of 2018 and 2019, we can see how summing up the Porta Palazzo Market to the Mercato del Libero Scambio and the Balon (all markets near the trial), the total waste produced decreased by $11.3 \%$ thanks to a $9.5 \%$ drop in general waste production. The Balon in particular, only in the first half of 2019 , recycled over $80 \%$ of the collected waste, of which $1.6 \%$ was still edible.

Finally, associated with RePoPP, a communication campaign (Figure 2) was developed by UNISG aimed at increasing awareness and education regarding recycling and providing civic and environmental information to asylum seekers, creating entertainment activities on food waste and pushing social integration. The campaign took over the market square with provocative and ironic slogans, playing with the Italian language, that have come straight to people's hearts, speaking directly to consumers, traders, and volunteers (Figure 3) [67].

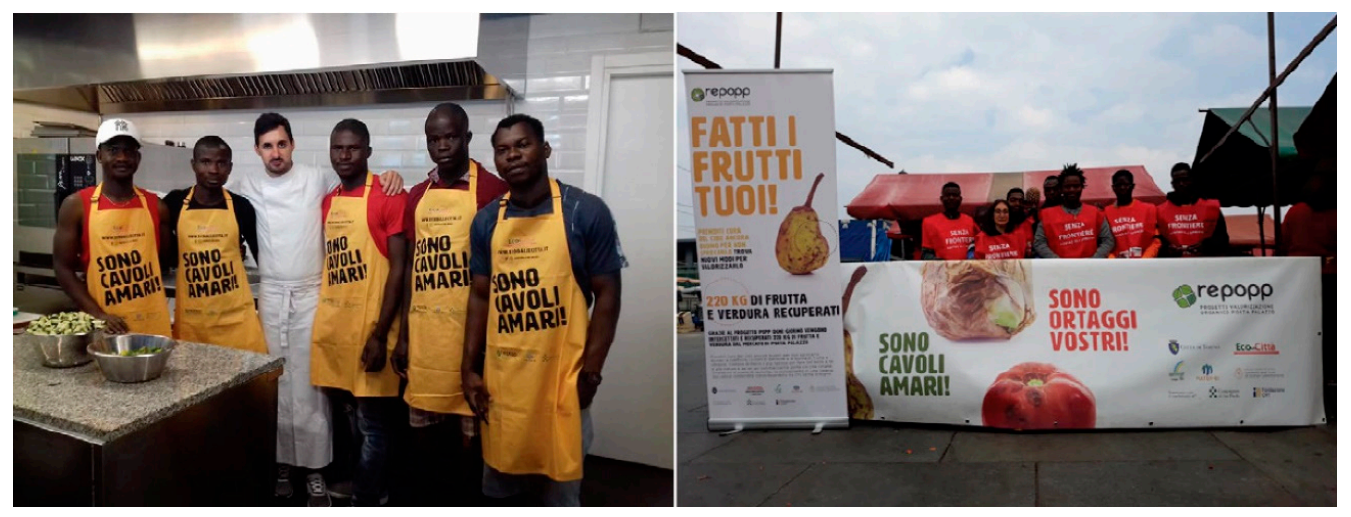

Figure 2. Volunteer asylum seekers (source: University of Gastronomic Sciences, 2018). 


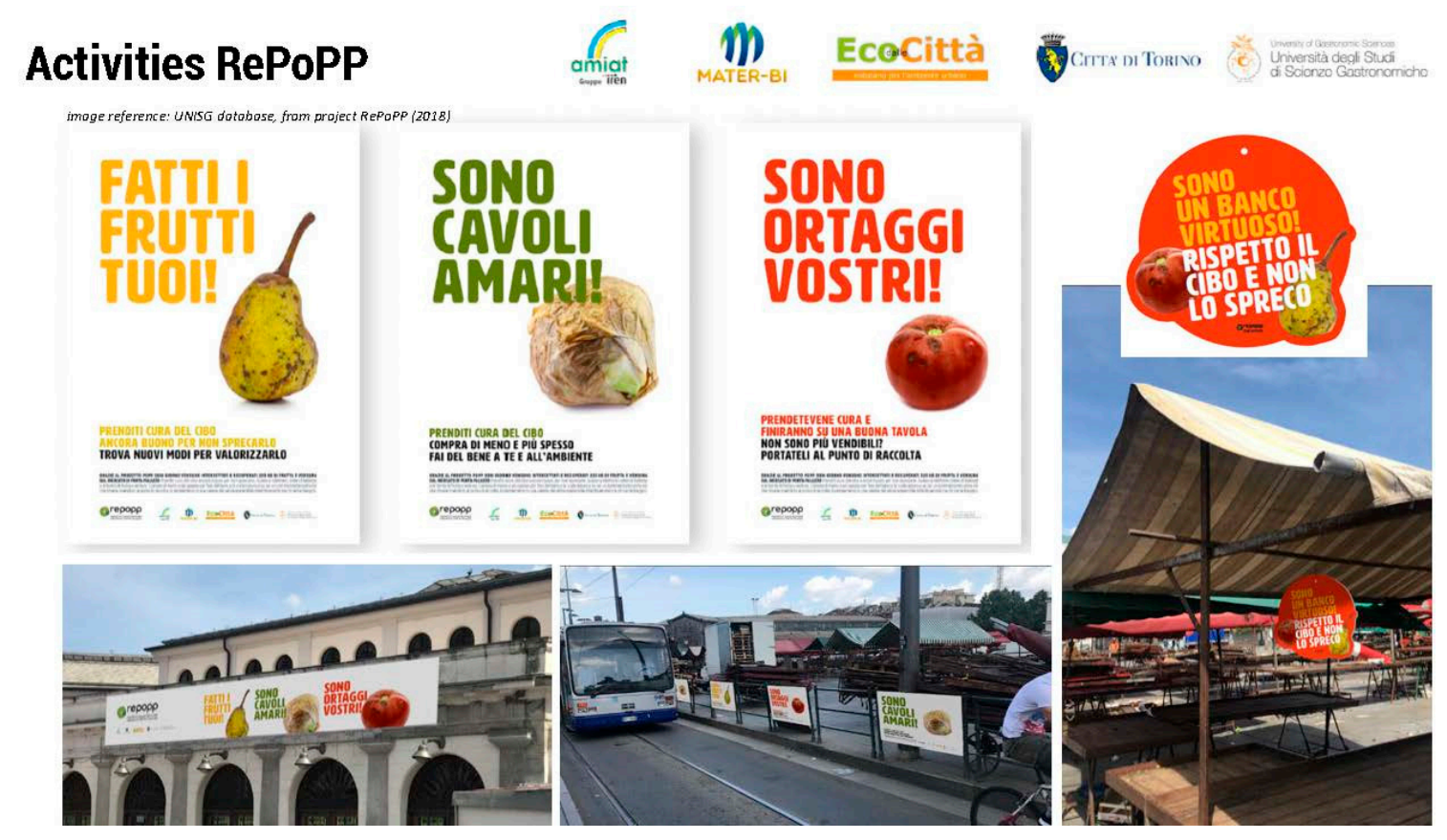

Figure 3. Communication campaign (source: University of Gastronomic Sciences, 2018).

RePoPP, besides collecting food surplus and increasing recycling and access to food, also worked on integration and social innovation. In 2018 the project won the special mention of the Milan Pact Award for the "food waste" category [68], based solely on the circular nature of the project. Furthermore, it was awarded with a Cresco Award in 2018, supported by the Sodalitas Foundation, in collaboration with ANCI (national organization of Italian municipalities), as one of the most effective urban Italian projects in the sustainable development of the territories. Finally, it received a special mention at the Oscars of Health, Rete Città Sane OMS, because of the relevance of its activities for the citizenship.

Today, the project has also been extended to other markets in the city thanks to Food Pride, a network of associations engaged in fighting food waste. The "food priders" collect unsold fruit and vegetables, expiring food, and also bread among the markets and shops of Turin by bicycle. This year, thanks to this project, in the Via Porpora Market, $1275 \mathrm{~kg}$ of food have already been collected, with a recovery of twice a week, and $3004 \mathrm{~kg}$ in the Borgo Vittoria Market, with a recovery of three times a week. More than 200 people benefit from the weekly redistribution of these products, in particular 160 beneficiaries from Porta Palazzo, 15 from Borgo Vittoria, and 32 from Via Porpora. Moreover, from February 2019, groups of asylum seekers and European volunteers of the Eufemia NGO, have used a cargo bike to recover and redistribute about $1000 \mathrm{~kg}$ of bread per month to the homeless dormitory in via Ghedini and to the Cecchi Point Multicultural Hub. Starting from March 2019, other associations joined the Food Pride project and today they manage the redistribution in markets that RePopp did not involve before: Mercato Corso Taranto, where two Italian volunteers from Rete Ong weekly collect, on average, $85 \mathrm{~kg}$ of food per month and redistribute it to 35 people; in the Corso Brunelleschi Market and in the Corso Racconigi Market, managed by Italian and European volunteers from the Eufemia association, the weekly collections generate about $930-980 \mathrm{~kg}$ per month, from which about 30-40 families benefit. To date, this initiative is expanding thanks to the involvement of other associations and other markets: a network of "Circular Markets" is being created, of which the University of Gastronomic Sciences is a promoter and spokesperson.

\section{Discussion}

RePoPP, a project born from Turin's local food policies and developed by adopting a circular approach to food, is a clear example of a new area of research and development, which could be internationally defined as circular economy for food policy. RePoPP is in line with the four 
converging perspectives described above, meaning that for each a direct application on the project has been identified. Crossing the design strategies adopted for the realization of RePoPP with the four converging perspectives, four fundamental application strategies emerge as possible common ground between circular economy for food and food policies (Table 2):

- Foundation A: Use of a systemic approach and CE to problems and solutions (sustainable strategies);

- Foundation B: transdisciplinary and integrated project design for the 9Rs (responsibility, react, reduce, reuse, re-design, repair, recover, recycle, and rot);

- Foundation C: Use of food as a pivot of cross-sectoral change (17 Sustainable Development Goals);

- Foundation D: Use of a new form of collaborative and integrated governance (urban food policies)

Table 2. Circular economy for new local policies: summary table.

\begin{tabular}{|c|c|c|c|c|c|}
\hline $\begin{array}{l}\text { Converging } \\
\text { Prespectives }\end{array}$ & + & RePoPP & $=$ & $\begin{array}{c}\text { Shared } \\
\text { Foundations }\end{array}$ & $\begin{array}{l}\text { Circular Economy for } \\
\text { Food Policy }\end{array}$ \\
\hline $\begin{array}{l}\text { The current } \\
\text { food system is } \\
\text { harmful and } \\
\text { unsustainable }\end{array}$ & + & $\begin{array}{l}\text { Systemic analysis of actors } \\
\text { and relations through the } \\
\text { Atlas of Food (holistic } \\
\text { relief of the local food } \\
\text { system) }\end{array}$ & $=$ & A & $\begin{array}{l}\text { Use of a systemic } \\
\text { approach and CE to } \\
\text { problems and solutions } \\
\text { (sustainable strategies) }\end{array}$ \\
\hline $\begin{array}{l}\text { A paradigm } \\
\text { shift is needed }\end{array}$ & + & $\begin{array}{l}\text { Reduction of general } \\
\text { waste, increase in } \\
\text { surpluses value, access to } \\
\text { food for the needy, social } \\
\text { integration, new jobs } \\
\text { (reduce, recover, humane } \\
\text { health) }\end{array}$ & $=$ & B & $\begin{array}{l}\text { Transdisciplinary and } \\
\text { integrated project design } \\
\text { for the 9R (systemic design } \\
\text { and gastronomic sciences) }\end{array}$ \\
\hline $\begin{array}{l}\text { Food as the } \\
\text { measure for } \\
\text { change }\end{array}$ & + & $\begin{array}{l}\text { Food and its by-products } \\
\text { are the focus of the activity } \\
\text { (CE for food) }\end{array}$ & $=$ & $\mathrm{C}$ & $\begin{array}{c}\text { Use of food as a pivot of } \\
\text { cross-sectoral change (17 } \\
\text { Sustainable Development } \\
\text { Goals) }\end{array}$ \\
\hline $\begin{array}{l}\text { A new } \\
\text { governance is } \\
\text { needed }\end{array}$ & + & $\begin{array}{l}\text { Collaboration among } \\
\text { public, private, third sector } \\
\text { (responsibility) }\end{array}$ & $=$ & $\mathrm{D}$ & $\begin{array}{l}\text { Use of a new form of } \\
\text { collaborative and } \\
\text { integrated governance } \\
\text { (urban food policies) }\end{array}$ \\
\hline
\end{tabular}

As Table 2 shows, the project was indeed born thanks to the identification of a series of problems related to the Turin urban food system, put into system also thanks to the research carried out by the Atlas of Food (foundation A). The systemic approach was used in the design and implementation of an innovative, original, transdisciplinary project aimed at changing citizens' habits, namely, proposing a new paradigm in the waste recycling and food surplus redistribution system, guaranteeing innovation and social integration (foundation B). As a starting point of this new paradigm, the project used food as a stimulus for cross-sectoral improvement (foundation C). Starting from the collection of the unsold food, the project had positive impacts on waste, society, and education. The success of the project is due to the creation and use of a new governance structure that welcomes actors of various kinds and backgrounds united by common and shared goals (foundation D).

This case study demonstrates that besides the use of CE to source sustainable food, to design healthy food products, and to reuse food waste/surplus [2], CE can be the origin of a holistic and systemic change. Indeed, RePoPP not only "designs out the food waste" [2], but also changes the design of food markets, the relationships between food actors, and the social inclusion dynamics: "The potential cascade effect of food practices in their cultural value and in their factual connections, their system pervasiveness, can become that flywheel by which, if aligned to the pivot of circular economy, the rotary 
movement can be brought to expand towards a new awareness of the interconnectivity of all things, of the fact that the circularity born of thinking in systems is not a new bond or constraint, but rather the natural result of an existing alliance between all parts" [16] (p. 74).

Working on urban projects of this type on a global scale, cities could create benefits of $\$ 2.7$ billion a year in 2050, reduce greenhouse gas emissions by an equivalent of 4.3 million tons of $\mathrm{CO}_{2}$, and save 15 million hectares of agricultural land from degradation [2]. Politics and policies need circularity and vice versa. The first requires a shared action tool and indicators, the second, regulations to achieve a global impact. Together, they can implement the paradigm shift that both seek long-term, contextualized and resilient to all the challenges that have not been considered yet. On the other hand, the systemic view includes cooperation between common thoughts. The CE, which became part of European priorities in December 2015, has already begun to stimulate a regulatory change necessary for a political and cultural evolution [47]. The food policies are still far from uniform and systematic, essentially because they are extremely variable in nature. The term itself, food policy, is used to identify policies but also policy implementation tools, depending on the context in which it is used [13]. Their multisectoral nature, historically treated in an extremely sectorial way, has made them difficult to understand and to organize [20]. Perhaps with the help of a growing tool such as the $\mathrm{CE}$, which currently already has a theoretical-regulatory framework, it will be easier to reach a common vision for global food policies. The CE should not only serve to redefine the concept of waste [16], but can help formulate projects and policies in all areas that food touches. Circularity is a mindset, a way of designing reality, a system that should be the basis of every urban policy, because undoubtedly, we are all part of the same system, hence, we need a circular economy for food policies.

\section{Conclusions}

This paper tried to set the basis for a new transdisciplinary scholarship, defined the circular economy for food policy (CEFFP), showing the convergences and applications that the use of CE can have, and should have, in the design of food system policies. The results of the RePoPP case study showed a positive answer to the question of whether the use of CE strategies helps bringing a socio-economic paradigm change in food policies. The project performed an interesting growth in a few years and produced positive results not only in the collection of food waste and redistribution of food surplus, but also as a social inclusion incentive and in the creation of a new systemic governance. The extension of the project to new markets showed interest from the city and the population, along with the possibility to easily replicate and adapt the best practice.

This article is trying to open a new theoretical path by proving a clear area of study which still has variable boundaries that should be defined in further research. By underling the linkages of these two connected scholarships, concatenated exploratory methodology [9] helped enlighten that a circular economy for food policy could be a win-win strategy: for CE to have a new platform of work that share same ideals and worldview, and for FP to have a set of structured indicators and strategies to create policies for a more sustainable future. As the beginning of a new fusion of two disciplines, CE and FP, this paper encountered many limitations and obstacles, firstly the lack of studies strictly related to the interconnections of these two areas of study. Further research should, therefore, focus not only on the design of new projects, such as RePoPP, but also on monitoring the current best practices. Indeed, the monitoring of circular economy for food activities is continuing at the University of Gastronomic Sciences, where over 200 case histories on the application of CE to food policies are now being classified. The main objective of this paper was to stimulate cities and academics to work with CE worldview and indicators, applying system design thinking and circularity to all food policies of the future.

Author Contributions: The whole article has been conceptualized, elaborated, and written with the collaboration of the two authors, except for the data regarding RePoPP and the Atlas of Food, which was harvested by F.F. only as scientific coordinator of the two projects.

Funding: The Research RePoPP was funded by Novamont. 
Conflicts of Interest: The authors declare no conflict of interest and that the funder and that all the other actors involved in the project agreed in publishing these data.

\section{Appendix A}

By overlapping the analysis of the recovery system and redistribution of food surpluses for social purposes with the production of food waste from different forms of distribution (large organized distribution, neighbourhood stores, markets, farmers' market, and GAS (solidarity purchasing groups), the Atlas of Food pointed out a potential leeway of intervention for new ways of value creation and optimisation. Once the critical hotspot and source of leakages in city district markets were identified, the attention has been focused on the market of Porta Palazzo, the largest outdoor European market.

\section{Example from ATLANTE DEL CIBO DI TORINO METROPOLITANA "Rapporto 0" analysis of the recovery system and redistribution of food surpluses for social purposes}
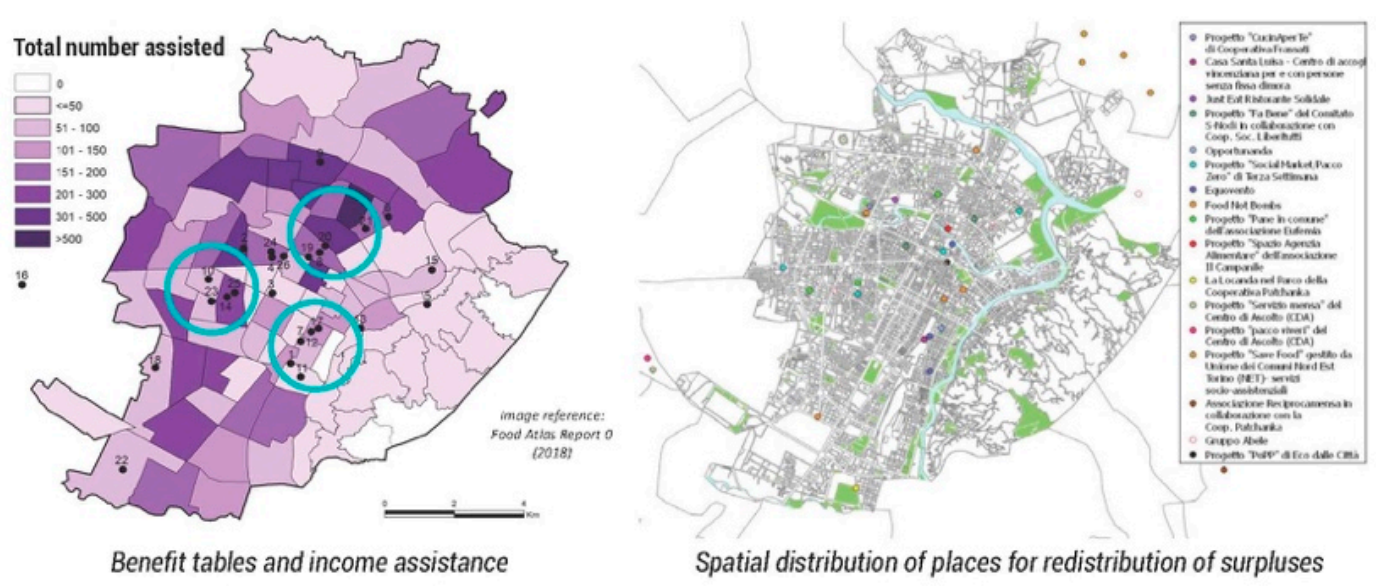

Figure A1. Analysis of the recovery system (Source: Atlante del Cibo di Torino Città Metropolitana, Report 0, 2017).

\section{Example from ATLANTE DEL CIBO DI TORINO METROPOLITANA "Rapporto 0" the forms of distribution: Large Organised Distribution, neighborhood stores, markets, farmers' market and Solidarity Purchasing Groups}
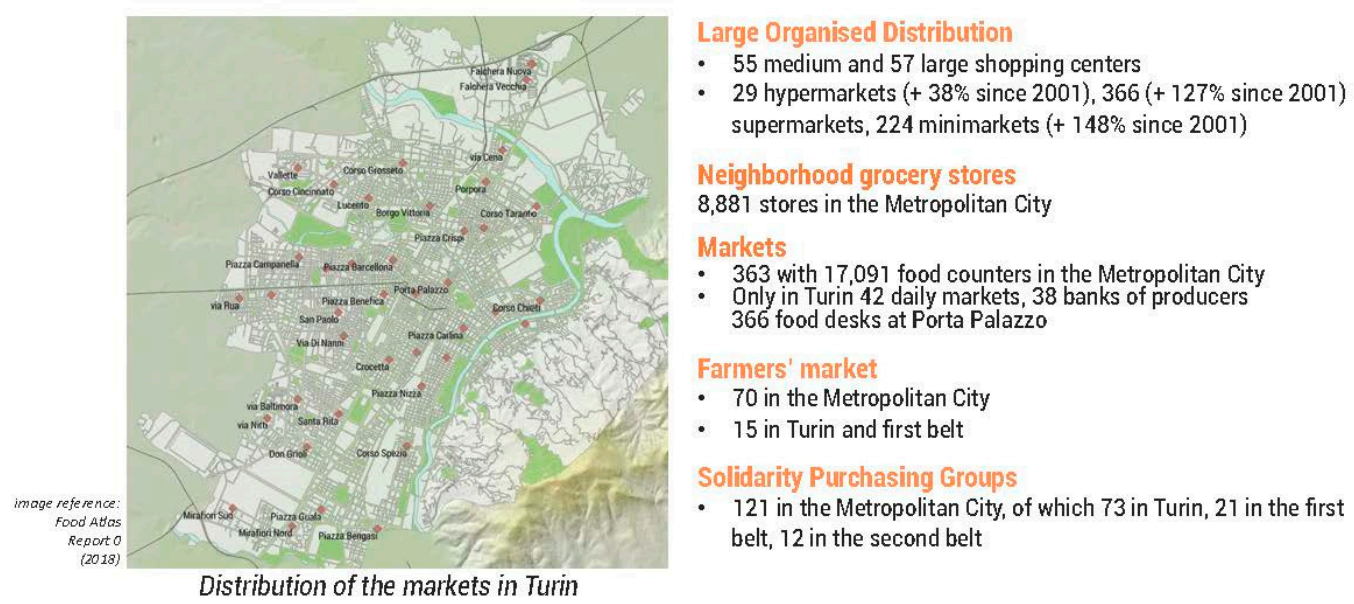

Figure A2. Different forms of distribution (Source: Atlante del Cibo di Torino Città Metropolitana, Report 0, 2017). 
The core of the Atlas is the evolution of the methodology for the analysis of urban food systems based on the realization of a multimedia, interactive, participated Atlas of Food, centered on the metropolitan city of Turin. The Atlas of food collects and organizes information and data about the food system at the metropolitan scale (the former province of Turin). The online platform (www.atlantedelcibo.it) presents the collected and newly produced, in the form of maps, and visual and textual materials, searchable and partially editable by the web community and by the actors of the food system. Data are participatory and regularly updated, basing the methodologies of civic participatory mapping of First Life, the civic map-based social network used for the participatory mapping activities of the Atlas of Food. Scales of the analysis and of the representation of the food system vary according to the treated issues, coherently with the transcalarity of food flows and networks. This flexible spatial approach helps in understanding the complexity of the food system and the connections between its multiple parts in and around the urban milieu (according to the systemic approach).

The general goal of the project is to develop and implement an interdisciplinary methodology of food system analysis and assessment, at the metropolitan scale, through traditional charts and maps, participatory mapping, and a strict relationship with social networks, for field action. The Atlas of Food of Turin has the following specific aims:

- to provide an open access tool, collecting and representing data, information, and ideas about the food system at the city-region scale;

- to support the public-private network which is working at the establishment of a food commission, through analysis of the food system, development of scenario and suggestions for the food strategies, design solutions aiming at the enhancement of sustainability, equity, participation and resilience of the food system;

- to increase the awareness of the actors of the food web about food, fostering the visibility and sharing of the issues linked to the different phases of the food chain;

- to provide a platform where the stronger and weaker actors of the food chain can virtually meet, reciprocally know, share ideas, creating an opinion making critical mass able to address food policies;

- to monitor the food system regularly with a participatory approach, reporting changes, trends, opportunities and threats.

The Atlas of Food can support the development of a resilient urban (food) system, because it stimulates the creation of a consistent database and repository of information about it. The research group carries out this work in strict collaboration with public authorities and agencies, other research bodies, private businesses, NGOs, and other community groups. This variety of public and private actors helps to guarantee the reliability, transparency, and regular update of the information presented by the website. The participatory approach concerns not only the data collection, but also the elaboration of development and policy scenarios, towards the planning of an efficient, resilient, fair, and sustainable metropolitan food system, where food and its connections have a role of social, economic and cultural capital.

The first report on the state of the Metropolitan Turin Food System, produced within the framework of the Atlas of Food, was presented in May 2017. It was divided into three main sections: (a) a review of already existing maps and representations about the food system (a map of maps), which were critically reviewed and organized, in order to produce a catalogue of the different existing representations; (b) a collection of static maps, specifically produced for the atlas, representing data about the food system coming both from official archives (e.g., census) and from users and actors of the food system. The static maps will be open to updates and corrections, following the suggestions of users; (c) a platform for user-generated, dynamic, interactive maps, based on crowd mapping and the integration with social networks. It provides a first cross-cutting and integrated reading of the main features of the metropolitan food system. 


\section{References}

1. United Nations (UN). World Urbanization Prospects. The 2018 Revision-Key Facts. Available online: https://population.un.org/wup/Publications/Files/WUP2018-KeyFacts.pdf (accessed on 20 June 2019).

2. Ellen Macarthur Foundation (EMF). Cities and Circular Economy for Food. Available online: https://www. ellenmacarthurfoundation.org/publications/cities-and-circular-economy-for-food (accessed on 20 June 2019).

3. Hawkes, C.; Halliday, J. What Makes Urban Food Policy Happen? Insights from Five Case Studies. Available online: http://www.ipes-food.org/_img/upload/files/Cities_full.pdf (accessed on 20 June 2019).

4. ENEL. Cities of Tomorrow, Circular Cities. Available online: https://www.enel.com/content/dam/enel-com/ media/document/cities-of-tomorrow_en.pdf (accessed on 20 June 2019).

5. Caraher, M.; Reynolds, J. Sustainability-considering the pillars of sustainability as a theoretical paradigm. J. Home Econ. Inst. Aust. 2005, 12, 2-15.

6. Hawkes, C.; Demaio, A.R.; Branca, F. Double-duty actions for ending malnutrition within a decade. Lancet Glob. Health 2017, 5, e745-e746. [CrossRef]

7. World Health Organization (WHO). World Health Statistics 2017: Monitoring Health for the SGDs. Available online: https://apps.who.int/iris/bitstream/handle/10665/255336/9789241565486-eng.pdf; jsessionid=907B95BBE338F348F7AEE3C264F0713F?sequence=1 (accessed on 12 July 2019).

8. United Nations (UN). Sustainable Development Goals Knowledge Platform. Available online: https: //sustainabledevelopment.un.org/?menu=1300 (accessed on 12 July 2019).

9. Beauregard, R. La Città Eterogenea; Fondazione Gian Giacomo Feltrinelli: Milano, Italy, 2015.

10. Kummitha, R.K.R.; Crutzen, N. How do we understand smart cities? An evolutionary perspective. Cities 2017, 67, 43-52. [CrossRef]

11. Ahvenniemi, H.; Huovila, A.; Pinto-Seppä, I.; Airaksinen, M. What are the differences between sustainable and smart cities? Cities 2017, 60, 234-245. [CrossRef]

12. Maye, D. Smart Cities Food Governance: Critical Perspectives from Innovation Theory and Urban Food System Planning. In The Governance of City Food Systems; Fondazione Giangiacomo Feltrinelli: Milan, Italy, 2016; p. 4967.

13. Calori, A.; Magarini, A. Food and the Cities: Politiche del Cibo Per Città Sostenibili; Edizioni Ambiente: Milano, Italy, 2015.

14. International Panel of Experts on Sustainable Food Systems (IPES). Towards a Common Food Policy for the European Union. The Policy Reform and Realignment that is Required to Build Sustainable Food Systems in Europe. Available online: http://www.ipes-food.org/_img/upload/files/CFP_FullReport.pdf (accessed on 20 June 2019).

15. Capra, F. The Web of Life: A New Synthesis of Mind and Matter; HarperCollins: London, UK, 1996.

16. Fassio, F.; Tecco, N. Circular Economy for Food: Materia, Energia e Conoscenza in Circolo; Edizioni Ambiente: Milano, Italy, 2018.

17. Meadows, D.H. Thinking in Systems: A Primer; Chelsea Green Publishing: White River Junction, VT, USA, 2008.

18. Glaser, B.G.; Strauss, A.L. Discovery of Grounded Theory: Strategies for Qualitative Research; Routledge: Abingdon, UK, 2017.

19. Stebbins, R.A. Exploratory Research in the Social Sciences. Qualitative Research Methods; SAGE Publications Inc.: Thousand Oaks, CA, USA, 2001.

20. Lang, T.; Barling, D.; Caraher, M. Food Policy: Integrating Health, Environment and Society; OUP Oxford: Oxford, UK, 2009.

21. Harper, A.; Shattuck, A.; Holt-Giménez, E.; Alkon, A.; Lambrick, F. Food policy councils: Lessons learned. Inst. Food Dev. Policy 2009, 1-63.

22. Barling, D.; Lang, T.; Caraher, M. Joined-up food policy? The trials of governance, public policy and the food system. Soc. Policy Adm. 2002, 36, 556-574. [CrossRef]

23. Wiskerke, J.S. On places lost and places regained: Reflections on the alternative food geography and sustainable regional development. Int. Plan. Stud. 2009, 14, 369-387. [CrossRef]

24. Lovins, A.B.; Lovins, L.H.; Hawken, P. A Road Map for Natural Capitalism (HBR Paperback Reprint 2000). Harv. Bus. Rev. 1999, 1-14.

25. Bourdieu, P. Le capital social: Notes provisoires. Actes de la Recherche En Sciences Sociales 1980, 31, 2-3. [CrossRef] 
26. Rockström, J.; Steffen, W.L.; Noone, K.; Persson, Å.; Chapin, F.S., III; Lambin, E.; Nykvist, B. Planetary boundaries: Exploring the safe operating space for humanity. Ecol. Soc. 2009, 14, 32. [CrossRef]

27. Raworth, K. Doughnut Economics: Seven Ways to Think Like a 21st-Century Economist; Chelsea Green Publishing: White River Junction, VT, USA, 2017.

28. Bertalanffy, L. General System Theory-A Critical Review. In Modern Systems Research for the Behavioral Scientist; Aldine: Chicago, IL, USA, 1968; pp. 11-30.

29. Maturana, H.R.; Varela, F.J. Autopoiesis and Cognition: The Realization of the Living; Springer Science \& Business Media: Berlin, Germany, 1991; Volume 42.

30. Meadows, D.H. Pensare per Sistemi, Interpretare il Presente, Orientare il Futuro Verso uno Sviluppo Sostenibile; Guerini Next: Milan, Italy, 2019.

31. Ghisellini, P.; Cialani, C.; Ulgiati, S. A review on circular economy: The expected transition to a balanced interplay of environmental and economic systems. J. Clean. Prod. 2015, 114, 11-32. [CrossRef]

32. Kirchherr, J.; Reike, D.; Hekkert, M. Conceptualizing the circular economy: An analysis of 114 definitions. Resour. Conserv. Recycl. 2017, 127, 221-231. [CrossRef]

33. Pomponi, F.; Moncaster, A. Circular Economy for the built environment: A research framework. J. Clean. Prod. 2016, 143, 710-718. [CrossRef]

34. Korhonen, J.; Nuur, C.; Feldmann, A.; Birkie, E.S. Circular Economy as an essential contested concept. J. Clean. Prod. 2017, 175, 544-552. [CrossRef]

35. Nestle, M. Food Politics: How the Food Industry Influences Nutrition and Health; University of California Press: Berkeley, CA, USA, 2013; Volume 3.

36. Lang, T.; Heasman, M. Food Wars: The Global Battle for Mouths, Minds and Markets; Routledge: Abingdon, UK, 2015.

37. Lang, T. Refashioning Food Systems with Sustainable Diets Guidelines: Towards a SDG Strategy. Available online: https://foodresearch.org.uk/publications/re-fashioning-food-systems-with-sustainablediet-guidelines (accessed on 10 September 2019).

38. Maxwell, S.; Slater, R. Food policy old and new. Dev. Policy Rev. 2003, 21, 531-553. [CrossRef]

39. Maslow, A.H. The Role of Basic Need Gratification in Psychological Theory in Motivation and Personality; Harper \& Row: New York, NY, USA, 1955.

40. Einstein, A. Mein Weltbild; Nijmegen-GJ Thieme: Nijmegen, The Netherlands, 1934.

41. Food and Agriculture Organization (FAO). Global Initiative on Food Loos and Waste reduction. Available online: http://www.fao.org/3/a-i4068e.pdf (accessed on 20 June 2019).

42. FAO; IFAD; WFP. Achieving Zero Hunger: The Critical Role of Investments in Social Protection and Agriculture. Available online: http://www.fao.org/3/a-i4951e.pdf (accessed on 20 June 2019).

43. Food and Agriculture Organization (FAO). Food Wastage Footprint. Impacts on Natural Resources. Summary Report. Available online: http://www.fao.org/3/i3347e/i3347e.pdf (accessed on 20 June 2019).

44. United Nations Environment Program (UNEP). Global Material Flow and Resource Productivity. Available online: https://www.resourcepanel.org/sites/default/files/documents/document/media/global_ material_flows_full_report_english.pdf (accessed on 20 June 2019).

45. International Energy Agency (IEA). World Energy Outlook. Available online: https://www.iea.org/Textbase/ npsum/WEO2016SUM.pdf (accessed on 20 June 2019).

46. Barilla for Food \& Nutrition (BCFN). Eating Planet. Cibo e Sostenibilità: Costruire il Nostro Futuro; Edizioni Ambiente: Milano, Italy, 2016.

47. Willett, W.; Rockström, J.; Loken, B.; Springmann, M.; Lang, T.; Vermeulen, S.; Jonell, M. Food in the Anthropocene: The EAT-Lancet Commission on healthy diets from sustainable food systems. Lancet 2019, 393, 447-492. [CrossRef]

48. Circle Economy. The Circularity Gap Report 2019. Available online: https://docs.wixstatic.com/ugd/ad6e59_ ba1e4d16c64f44fa94fbd8708eae8e34.pdf (accessed on 20 June 2019).

49. Forrester, J.W. Industrial Dynamics; Pegasus Communications: Arcadia, CA, USA, 1961.

50. Stapp, H.P. Bell's theorem and world process. Il Nuovo Cimento B (1971-1996) 1975, 29, 270-276. [CrossRef]

51. Rockström, J.; Sukhdev, P. How Food Connects all the SDGs; Opening Key Note Speech at the 2016 EAT Forum; Stockholm Resilience Centre: Stockholm, Sweden, 2016.

52. Graham, J.; Amos, B.; Plumptre, T. Principles for Good Governance in the 21st Century, Policy Brief $N^{\circ} 15$; Institute on Governance: Ottawa, ON, Canada, 2003.

53. Bateson, G.; Longo, G. Verso Un'ecologia Della Mente; Adelphi: Garden City, NY, USA, 1988; Volume 17.

54. Piaget, J.; Inhelder, B. La Psicologia del Bambino; Einaudi: Torino, Italy, 1970. 
55. Morin, E. Il Metodo 5. L'identità Umana; Raffaello Cortina Editore: Milano, Italy, 2002.

56. Haysom, G. Food and the City: Urban Scale Food System Governance. In Urban Forum; Springer: Berlin/Heidelberg, Germany, 2015; Volume 26, No. 3; pp. 263-281.

57. Morgan, K.; Sonnino, R. The urban foodscape: World cities and the new food equation. Camb. J. Reg. Econ. Soc. 2010, 3, 209-224. [CrossRef]

58. FAO; MUFPP. Està. Dakar: Creating Microgardens Using Recycled Materials. Available online: http://www. milanurbanfoodpolicypact.org/wp-content/uploads/2018/07/Brief-3-Dakar.pdf (accessed on 20 June 2019).

59. FAO; MUFPP. Està. Daegu: Mitigating Climate Change Through Urban Agriculture. Available online: http:// www.milanurbanfoodpolicypact.org/wp-content/uploads/2018/07/Brief-21-Daegu.pdf (accessed on 20 June 2019).

60. FAO; MUFPP. Està. Porto Alegre: A Peri Urban Processing Unit to Provide the City with Organic Oil and Byproducts. Available online: http://www.milanurbanfoodpolicypact.org/wp-content/uploads/2018/07/Brief31-Porto-Alegre.pdf (accessed on 20 June 2019).

61. FoodMetres. Metropolitan Regions: Case Study Region Ljubljana (Slovenia). Available online: http: //www.foodmetres-kp.eu/page.1.3.php (accessed on 20 June 2019).

62. Food City. Food City: The Major Wholesale Food Distribution Center. Available online: https://foodcity.ru/en (accessed on 20 June 2019).

63. City of Vienna. ÖkoKauf Wien-Programme for Sustainable Public Procurement. Available online: https://www.wien.gv.at/english/environment/protection/oekokauf (accessed on 20 June 2019).

64. Eko Getlini. Eko Getlini. Available online: http://www.getlini.lv/en (accessed on 20 June 2019).

65. Milano Food Policy. Hub di Quartiere Contro lo Spreco Alimentare. Available online: http://www. foodpolicymilano.org/hub-spreco-municipio9 (accessed on 20 June 2019).

66. Dansero, E.; Fassio, F.; Tamborrini, P. Atlante del Cibo_Report 2017. Available online: https://issuu.com/ francesco_cordola/docs/rapporto_2017 (accessed on 20 June 2019).

67. University of Gastronomic Sciences of Pollenzo. Al Progetto "RePoPP" va il Cresco Awards di Fondazione Sodalitas e ANCI. Available online: https:/www.unisg.it/comunicati/progetto-repopp-cresco-awardsfondazione-sodalitas-anci/ (accessed on 2 July 2019).

68. Milan Urban Food Policy Pact (MUFPP). Ghent and Lima won MPA 2018. Available online: http://www. milanurbanfoodpolicypact.org/2018/09/05/ghent-lima-win-mpa-2018-monetary-prizes (accessed on 2 July 2019).

(C) 2019 by the authors. Licensee MDPI, Basel, Switzerland. This article is an open access article distributed under the terms and conditions of the Creative Commons Attribution (CC BY) license (http://creativecommons.org/licenses/by/4.0/). 